\title{
THE EFFECTS OF A SIMPLER CRIMINAL PROCEDURE ON CRIMINAL CASE OUTCOMES: EVIDENCE FROM CZECH DISTRICT-LEVEL DATA
}

\section{Libor Dušek}

Cha rles University

Centerfor Economic Research and Graduate Education

Academy of Sciences of the Czech Republic

Economic Institute

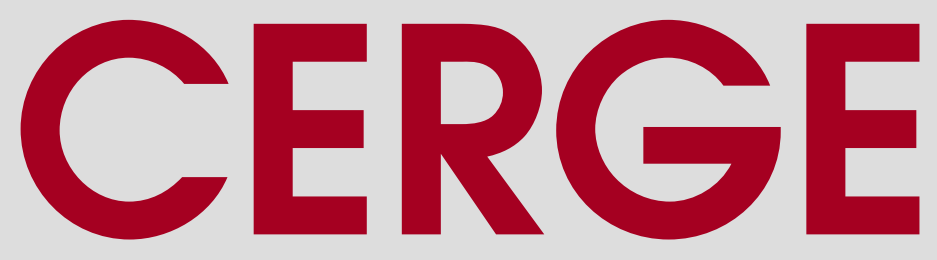




\section{Working Paper Series $\quad 528$ (ISSN 1211-3298)}

\section{The Effects of a Simpler Criminal Procedure on Criminal Case Outcomes: Evidence from Czech District-level Data}

Libor Dušek

CERGE-EI

Prague, January 2015 
ISBN 978-80-7343-333-8 (Univerzita Karlova. Centrum pro ekonomický výzkum a doktorské studium)

ISBN 978-80-7344-325-2 (Akademie věd České republiky. Národohospodářský ústav) 


\title{
The Effects of a Simpler Criminal Procedure on Criminal Case Outcomes: Evidence from Czech District-level Data
}

\author{
Libor Dušek *
}

\begin{abstract}
The paper estimates the effects of a simpler criminal procedure on case durations and the probabilities that the defendant is charged and convicted. The identification strategy exploits a policy reform in the Czech Republic as a quasi-natural experiment. The reform allowed petty offenses to be prosecuted via a simplified (fast-track) procedure but its actual implementation varied substantially across districts. The fast-track procedure reduced the average duration of the police/prosecutor phase of the criminal procedure by 27 days on average for the petty offenses. It increased the probability that the suspect is charged by 6 percentage points. The fast-track procedure released resources that could potentially be spent on prosecuting serious crimes; I therefore investigate for spillover effects. I find only weak evidence of such spillover effects on the probability that the suspect is charged and no evidence of spillover effects on other case outcomes.
\end{abstract}

\begin{abstract}
Abstrakt
Článek odhaduje dopady jednodušší trestní procedury na délku trestního řízení a na pravděpodobnost obžaloby a odsouzení obviněného. K identifikaci odhadů využívám trestně-procesní reformy v České republice jako přirozeného experimentu. Reforma z roku 2002 umožnila stíhat bagatelní trestné činy formou tzv. zkráceného přípravného řízení, ale byla implementována s rozdílnou intenzitou v různých okresech. Zkrácené přípravné řízení zkrátilo délku trestního řízení u policie a státního zástupce v průměru o 27 dní u bagatelních případů. Zvýšilo pravděpodobnost, že obviněný je obžalován, o 6 procentních bodů. Zkrácené př́pravné řízení uvolnilo zdroje, které mohly být potenciálně využity ke stíhání závažných případů. Zkoumám tedy i vedlejší efekty na závažné případy. Výsledky naznačují jen slabé vedlejší efekty na pravděpodobnost obžaloby a žádné vedlejší efekty na jiné výsledky trestního řízení.
\end{abstract}

JEL classification: K14, K41, K42

Keywords: criminal procedure, law enforcement

*Assistant Professor, Univesity of Economics, Prague, and IDEA Researcher, CERGE-EI. CERGE-EI is a joint workplace of the Center for Economic Research and Graduate Education, Charles University in Prague, and the Economics Institute of the ASCR, v.v.i. CERGE-EI, P. O. Box 882, Politickych veznu 7, 11121 Prague, Czech Republic. E-mail: libor.dusek@cerge-ei.cz. I appreciate comments received from Alena Bicakova, Patrick Gaule, Josef Montag, and participants at the EALE conference and seminars at VSE and Copenhagen Business School. I am grateful to Petr Koucky from the Ministry of Justice and Vladimir Stolin from the Police Presidium for making the data available and to Branislav Zudel, Marek Pekoc, and Vojtech Zika for research assistance. The financial support from IGA grant no. IG505023 is acknowledged. All errors remaining in this text are the responsibility of the author. 


\section{Introduction}

The design of the criminal procedure has to strike a delicate trade-off between competing objectives: assuring that guilty defendants are convicted; assuring that innocent defendants are acquitted; economizing on the costs of police, prosecutors, judges, defendants, and attorneys; and minimizing the duration of the procedure from the committing of the crime until the actual imposition of the punishment.

The trade-off between the first two objectives has been studied extensively in the theoretical law and economics literature. Most papers (e.g. Andreoni 1991, Rizzolli 2011, Kaplow 2012) search for the optimal standard of proof, that is, the level of evidence required to convict a defendant. However, collecting evidence and reaching a final verdict requires a substantial input of time and other resources from the policemen, prosecutors and judges. The rules of the criminal procedure guide and constrain the actions of the enforcement officials. Rules that are more formal and grant defendants more procedural rights may lead to more precise verdicts; on the other hand, they may lead to very expensive and lengthy criminal trials. Lengthy and formalistic procedure may also negatively affect the probability of punishment. As the time passes, the quality of the evidence deteriorates or the defendant is more likely to turn fugitive. A complex procedure with many steps increases the probability that the defendant will exploit a procedural loophole or witnesses modify their original testimonies.

Delays in the criminal justice process are a serious problem in most countries, and they have many undesirable consequences, including effects on crime (Pellegrina 2008). Many countries take policy measures to reduce the duration of the criminal procedure. There are two broad approaches to doing so:

- Hiring more policemen, prosecutors and judges - i.e., using more inputs to produce more enforcement output, holding the production technology constant. 
- Simplifying the procedure - i.e., changing the production technology, therefore allowing more enforcement output to be produced with the same amount of input.

Recent studies on the efficacy of the first approach include Beenstock and Haitovsky (2004) and Dimitrova-Grajzl et al (2012) who investigate the effects of hiring more judges (in Israel and Slovenia respectively) on the number of cases that are resolved. Both find that an increase in the number of judges has a very small effect on the number of cases resolved and the pending caseload, the extra manpower being largely offset by a reduced productivity per judge and by an increased number of cases filed. Huang (2011) investigates the reverse case, when the caseload of two U.S. federal courts of appeals increased suddenly by 40 percent due to a flood of immigration cases. This had an effect on the outcomes of non-immigration cases, where the courts were more likely to dismiss the cases before reaching the decisions on merit, and in the cases that did proceed to decisions on merit, they were less likely to reverse or remand. Soares and Sviatchi (2010) evaluate the effects of technological modernization in Costa Rican courts, finding an increase in clearance rates and a reduction in administrative costs per case.

The economics literature on the effects of the second approach has been centered around plea bargaining, a distinctly American procedure. The standard economic argument favors plea bargaining because it achieves convictions of the offenders who do plead guilty in a shorter time and at a lower cost. It therefore releases resources that can be used to prosecute the remaining cases. ${ }^{1}$ These cases can then also be resolved in a shorter time and with a higher probability of conviction at trial. Plea bargaining thus produces an important spillover effect on other cases.

Boari and Fiorentini (2001) is a rare empirical assessment of the effects of plea bargaining, exploiting the transplantation of plea bargaining in Italy. Bridges (1982)

\footnotetext{
${ }^{1}$ Easterbrook (1983). In contrast, Garoupa and Stephen (2008) give a more moderate view.
} 
evaluates a procedural reform that explicitly sought to shorten the duration of criminal cases: the Speedy Trial Act in the United States. The Act, however, administratively imposed strict time limits instead of simplifying the procedure per se. To my best knowledge, there is no study empirically investigating the effects of a procedural simplification within the traditional civil law framework of a public prosecutor and mandatory court trial.

This paper fills this gap in the literature. It exploits a criminal procedure reform in the Czech Republic as a "quasi-natural experiment" to test the effects of a simpler criminal procedure on criminal case outcomes, namely case duration, the probability that an identified suspect is charged in court, and the probability that a charged suspect is convicted at trial. The reform was adopted in 2002. It allowed evidentially simple crimes to be prosecuted via a "fast-track" procedure. The new procedure removed several procedural steps and substantially simplified the paperwork. The stated objectives of the reform were to save resources in the enforcement of petty crimes and to release resources for the enforcement of serious crimes. ${ }^{2}$ In this sense, the introduction of the fast-track procedure is economically similar to introducing plea bargaining, although only for a limited number of offenses.

The number of cases in a given offense category that are actually prosecuted via the fast track depends on the number of cases that meet the eligibility criteria and on a discretionary decision of the police officer to prosecute the case via the fast track. In practice, the implementation of the fast-track procedure was gradual and varied substantially across offenses and districts. The fast-track procedure became used most intensively for thefts and for offenses related to driving because these are exactly the offenses where the offender is prosecuted after being caught on the spot and the evidence is thus straightforward. The share of thefts prosecuted via the fast track was 23 percent on average in the first post-reform year, while it varied from 6 to 43 percent across districts. Similar variation is observed for all offenses, and

\footnotetext{
${ }^{2}$ Ministry of Justice of the Czech Republic (2001).
} 
it has persisted over time. In previous research (Dušek 2014), I document that the variation across districts is largely due to "local law" - administrative and ideological preferences of police officers and prosecutors. Importantly, the intensity of fast track adoption was not related to the pre-reform trends in the case duration or crime rates in a district.

The variation across districts is exploited to estimate its effects on the criminal case outcomes in a difference-in-differences framework. The dataset is a panel of 86 Czech districts and 11 offense categories covering 1998-2008. It contains detailed information on the criminal justice process: the number of cases handled by the prosecutor, the number of cases prosecuted via the fast-track or conventional procedure, the fraction of defendants that were charged and eventually convicted. It also contains detailed information on durations (e.g. the average time from offense to charges and the final adjudication) and the average characteristics of the offender and the case.

I present a simple theoretical framework in order to show that the reform could have affected the criminal case outcomes through two distinct effects: a direct effect on offenses that are prosecuted relatively intensively through the fast-track procedure (covered offenses) and a spillover effect on other offenses (typically more serious offenses) that are prosecuted via the fast-track procedure only sporadically or not at all. Then I estimate these effects by regressing the case outcomes on an average case, offender and district characteristics, year dummies and interaction of district dummies with a time trend. Most importantly, the regressions include the share of fast-track cases in a given offense (to capture the direct effect) and the overall share of fast-track cases (to capture the spillover effect).

I find statistically and economically significant direct effects on the duration of the case from offense to charges. A 10-percentage point increase in the share of fasttrack cases translates into a reduction in the duration by 9 to 35 days for the covered offenses. The durations were declining throughout the post-reform period, from 256 
to 200 days on average for covered offenses. The estimates imply that the fast-track procedure, as actually implemented, contributed 27 days to this decline. The direct effects on the duration of the court phase (from charges to final adjudication) are smaller in magnitude and significant only for two offense categories.

I also find significant positive direct effects on the probability that the identified suspect is eventually charged, which was 69 percent on average before the reform for covered offenses. A 10 percentage point increase in the fast-track share translates into an increase in this probability by 1 to 3 percentage points, depending on the offense. The probability of charges increased by 11 percentage points during the post-reform period, and the estimates imply that the fast-track procedure contributed 6 percentage points to this increase.

I find no evidence of spillover effects on case durations and the probability of conviction at trial. I find some, but statistically weak, evidence of a spillover effect on the probability of charges, particularly for robbery, sex crimes, and crimes against family.

These findings give some empirical insights into the economics of criminal procedure. Criminal justice systems that are burdened with a large caseload can simultaneously improve case durations and the productivity of law enforcers by simplifying the criminal procedure. The lack of evidence of spillover effects does not provide support for the resource-releasing hypothesis that the standard economic models use in the defence of plea bargaining. I would argue that cost-reducing procedural innovation, such as the fast-track procedure or plea bargaining, does not only release enforcement resources, but it also leads to their reallocation. If the costs of enforcing petty cases fall, enforcers have an incentive to pursue the petty cases more vigorously. This reallocation - undesirable from the policy perspective - mitigates the spillover effect. The previous findings (Dušek 2014) of a substantial increase in the number of driving-related offenses is consistent with the reallocation hypothesis and provides 
a possible explanation for the absence of the spillover effect.

\section{Institutional background}

Prior to the 2002 reform the Czech Criminal Procedure Code prescribed a unified procedure applicable to all crimes. Practitioners generally agreed that the procedure was unnecessarily burdensome, lengthy and expensive for less serious crimes and for crimes where the evidence clearly indicated guilt. The reform introduced a so-called fast-track criminal procedure. ${ }^{3}$ Only cases that meet the eligibility criteria can be prosecuted via the fast-track procedure:

1) They fall into the jurisdiction of the district court (i.e., the lowest court level).

2) The maximum punishment set by the Criminal Code does not exceed three years of imprisonment.

3) The suspect was either identified while committing the crime or immediately after, or the evidence revealed in the early stage of the investigation is sufficient to prosecute the suspect and there is a reasonable chance that the suspect can be brought to trial in two weeks.

The fast-track procedure reduced administrative paperwork, eliminated several procedural steps carried out by the prosecutor or the court, and imposed stricter deadlines. Under the conventional procedure, the police, upon identifying the suspect based on the collected evidence, would formally accuse the defendant. From that point on, the police would essentially repeat the collection of evidence (e.g., interrogating witnesses again) while the suspect has broad procedural rights (e.g., to read and comment on the testimonies provided by the witnesses). The case would then be bound over to the state attorney who would review it and charge the defendant at court. The court could hold a preliminary hearing; then, at trial, the evidence

\footnotetext{
3 "Zkrácené připravní řizeni” in Czech. The reform was legislated by Act no. 265/2001.
} 
would be re-presented and assessed by the judge. The deadlines faced by the law enforcers are reasonably flexible. ${ }^{4}$

Under the fast-track procedure, the police accuses the defendant and hands the case over to the state attorney, who reviews the case and charges the defendant in the court. The text of the prosecution is simpler (containing the description of the case and the proposed punishment, but not the legal justification or the description of the evidence). The trial is also simplified: with the consent of the defendant, the judge may declare certain facts of the case indisputable and hence the evidence need not be presented at trial; there are no closing speeches, etc. The deadlines are far stricter: the police have to hand over the case to the prosecutor within two weeks of the crime being reported. The prosecutor may, upon request, prolong the deadline by ten days at most; if the deadline is missed, the case reverts to the conventional procedure. The risk of reverting the case to the time-consuming conventional procedure gives the law enforcers strong incentives to meet the deadlines. ${ }^{5}$

The decision whether to initiate the fast-track or conventional procedure rests with the district-level state police officer ${ }^{6}$, although the prosecutor may reverse that decision. In practice, the two typically discuss each case informally but reversals of the initial police officer's decisions are rare. The letter of the legislation prescribes that all eligible cases should be prosecuted via the fast-track procedure. In reality, the officers exercise discretion and cases that are eligible for fast track may be prosecuted via the conventional procedure. Once set, the procedure "sticks" with the case. The court has to adjudicate the case through the procedure that was submitted by the prosecutor.

\footnotetext{
${ }^{4}$ For example, the police are supposed to hand over the less serious cases to the prosecutor within 2 months. However, if they fail to meet the deadline, they have to merely justify that to the prosecutor who sets a new deadline.

${ }^{5}$ According to the conversations with the practitioners, the fast-track cases are typically handed over to the court either in a day or two, or at the two-week deadline.

${ }^{6}$ Only the state police officers can handle criminal cases. Many cities have a city police, but its authority is limited to minor violations punishable by fines (e.g., traffic violations, loitering, graffiti). When the city police discovers an act that should be prosectued and punished according to the Criminal Code, it passes the case to the state police.
} 
The reform also made some changes to the conventional procedure. For example, it enhanced the powers of the prosecutor vis-à-vis the police, introduced some adversarial features, and shifted the burden of assessing the evidence from the police to the courts.

The reform was well received by the police and prosecutors. As the main advantages, they reported that the fast track significantly shortened the procedure, reduced the case backlog, and allowed investigative officers to focus on more complicated, serious cases. ${ }^{7}$ It allowed police officers at the local level to handle far more criminal cases. These police officers emphasized their satisfaction from handling criminal cases from the first contact with the crime all the way through to the prosecution; under the conventional procedure they would have to pass the case to a higher-level investigative officer without seeing the final result. A new criminal procedure reform of 2009 further expanded the range of offenses that can be prosecuted via the fasttrack procedure but also mitigated the incentives for the police officers to process cases quickly. For that reason, I evaluate the effects of the reform only during the period covered by the same post-reform legislation, between 2002 and 2008 .

The reform appears to have had an effect on the crime rates. In a related paper (Dušek 2014) I estimate its effects on crime rates, exploiting the variation in adoption across districts as in this paper. The fast-track procedure had a rather limited deterrent effect on some less serious crimes, namely burglary and embezzlement. However, it also lead to a substantial increase in offenses related to driving that are discovered and recorded mainly through the police's enforcement effort. The last finding is best rationalized as the reallocation of the police enforcement efforts towards crimes that became "cheaper" to prosecute.

\footnotetext{
${ }^{7}$ Zeman et al (2008), my own interviews with police officers.
} 


\section{Theoretical framework}

I present a very simple model in order to organize thinking about the predicted effects of the procedural reform described above. The basic idea comes from Landes' (1971) model of optimal prosecutor behavior. I modify his model to explicitly show the effects of a reduction in the cost of enforcement for a subset of offenses. Enforcement officials operate under resource constraints and have to allocate limited resources (their own time and material inputs) across individual cases. For simplicity, assume there are two types of case, serious offenses $(H)$ and petty offenses $(L)$. The output of the enforcement official's work is summarized in "success rates" $p_{H}$ and $p_{L}$, which would be the probabilities of identifying a suspect for a police officer, the probabilities of charging the defendant in court for a prosecutor, or the probabilities of conviction for a judge. The resource constraint is depicted as a curve $P P F_{1}$ in Figure 1, which shows the possible combinations of probabilities for serious and petty offenses. Allocating more resources to the enforcement of serious offenses increases $p_{H}$ but requires a reduction in resources allocated to the enforcement of petty resources and hence reduces $p_{L}$. The official is maximizing an objective function which is increasing in the probabilities of conviction; the exact shape of the function depends on the number of and harm from the petty and serious crimes, and possibly also his private objectives. The objective function is characterized by an indifference curve in Figure 1.

A procedural innovation such as the fast-track procedure reduces the cost of enforcement but only for the petty crimes. It shifts the resource constraint outwards $\left(P P F_{2}\right.$ in Figure 2), allowing the achievement of higher probabilities of conviction for both types of offenses with the same total resources. It also rotates the constraints such that it becomes flatter: the relative costs of enforcing petty offenses fall, allowing the enforcement official to achieve a greater increase in $p_{L}$ when shifting the same amount of resources from serious cases. 
The optimal response of the enforcement official is driven by substitution and scale effects. The substitution effect induces the enforcement official to shift resources towards petty crimes and away from serious crimes because petty crimes became relatively cheaper to enforce. The scale effect induces the official to allocate the released resources into both offense types and thus to increase output. Figure 2 depicts the resulting equilibrium response. The new procedure has an unambiguous effect on petty offenses, leading to an increase in $p_{L}$ because the substitution effect reinforces the scale effect. I refer to the sum of the substitution and scale effects on petty offenses as the direct effect. Less obviously, the new procedure has a spillover effect on serious offenses as well through the behavioral response of the enforcement official. The spillover effect has a theoretically ambiguous direction because the substitution effect mitigates the scale effect (Figure 2 is drawn such that the scale effect dominates, and the probability $p_{H}$ therefore increases). ${ }^{8}$

To summarize, the model predicts that the fast-track procedure should increase the probability of conviction for the petty offenses that were actually covered by the fast-track procedure, while it may increase or decrease the probability of conviction for other, more serious offenses. The effect on serious offenses is thus ultimately an empirical question.

\section{Empirical methodology}

\subsection{Data and summary statistics}

The dataset used in the analysis covers the four years before the procedural reform (1998-2001) and the severn years afterward (2002-2008). The unit of observation is a court district and an offense category. There are 86 court districts with an

\footnotetext{
${ }^{8}$ The theoretically predicted spillover effect is also the main reason why I do not exploit the variation in the share of fast-track cases across offenses as an additional source of identifying variation in the empirical analysis.
} 
average population of approximately 120,000 and 11 broader offense categories. The primary data sources are the administrative databases of prosecutorial and court cases provided by the Ministry of Justice. The database records every criminal case that reached the final decision of the prosecutor in the police/prosecutor phase or the final adjudication (including possible appeals) in the court phase. The databases contain the following information about the cases:

- The date when the crime was committed, the date the police accused the defendant, the date the prosecutor charged the defendant, the date when the case was received by the court, and the date of final adjudication outcome.

- The legal definition of the offenses (the exact section and subsection of the Czech Criminal Code). I aggregate these very detailed definitions to 11 broader offense categories. $^{9}$

- The final verdicts of the prosecutor (charging, dropping the charges, etc.) and the court (guilt, acquittal, the type and severity of punishment).

- Basic characteristics of the offender (gender, age, number of prior convictions).

- For cases prosecuted after the reform, an indicator whether the case was prosecuted via the conventional or fast-track procedure.

I constructed the following variables at the level of the district-year-offense, where year indicates the year when the offense was committed for the police/prosecutor phase and the year when the prosecutor bound the case over to the court for the court phase:

- The share of cases prosecuted via the fast-track procedure.

\footnotetext{
${ }^{9}$ To classify offenses, I separate several narrow offense definitions that are numerous (e.g., theft/burglary, robbery, driving offenses) and then assign the remaining less numerous offenses into broader categories following the broad categorization of the Czech Criminal Code. I exclude murders from the analysis. They are by default adjudicated by the higher-level courts, and the identifying variation at the district level therefore is not available.
} 
- Case durations: the average duration in days from offense to charges (when the prosecutor binds over the case to the court) and duration from charges to final adjudication.

- Case outcomes: the probability of charges (the fraction of accused offenders who were ultimately charged) and the conditional probability of conviction (the fraction of charged offenders who were ultimately convicted).

- Offender characteristics: the average age of the offender, the share of women and foreigners among offenders, and the average number of prior convictions.

- Case characteristics: the average number of charges per case (many offenders face multiple charges), the average maximum statutory sentence, and the fraction of defendants in pre-trial detention.

The case outcomes potentially depend on the caseload; I therefore construct three district-level measures of caseload: total number of crimes per police officer, total number of cases per prosecutor, and total number of cases per court senate. ${ }^{10}$

Table 1 shows the average characteristics of all cases, divided into the periods before and after the reform. The case duration before the reform was, on average, 362 days (police/prosecutor phase) and 249 days (court phase). These durations declined to 310 and 209 during the post-reform period. Likewise, the probability that the prosecutor brings charges averaged 68 percent before the reform and increased to 78 percent afterwards. The probability of conviction averaged around 82 percent both before and after the reform. Among the case characteristics, a noticeable difference between the pre-and post-reform period is the decline in the fraction of defendants

\footnotetext{
${ }^{10}$ The number of crimes and the number of police officers were obtained from the statistical records of the Police of the Czech Republic. The number of prosecutors in a district is contained indirectly in the prosecutor database because it reports a unique prosecutor identifier. The number of judges in a district is not, unfortunately, available in the court database. I therefore construct a proxy measure of court caseload, the number of cases per senate. The judges in a given court are always divided into senates, with a senate comprising typically of three judges. Finally, I also include the total district population as another control variable in the regressions.
} 
held in pre-trial detention and an increase in recidivism history. The fast-track procedure was used to prosecute $15 \%$ of cases in total throughout the post-reform period.

A cursory preview of the results is provided by Figures 3 through 6 . They show the evolution of the outcomes of interest, averaged at the country level. The offenses are divided into "covered" and "other" depending on whether they had an above-median or below-median share of the fast-track cases by the end of the sample period. The covered offenses still contain a large fraction of individual cases that are prosecuted via the conventional procedure, and the other offenses may contain a few cases that are prosecuted via the fast track; the two offense groups differ in the intensity of the actual use of the fast track. Hence there is no composition effect that would drive diverging trend between the two groups. The duration of the police/prosecutor phase of covered offenses started declining exactly when the reform was implemented. It declined by more than 100 days by 2008, despite a temporary rebound in the 3rd and 4th year after the reform. The duration of other offenses also declined, but it had been on a declining trend before the reform and stopped declining shortly afterwards. The duration of the procedure in court (Figure 4) declined by approximately 100 for covered offenses and by half as many days for other offenses.

Figure 5 plots the probability of charges. The reform led to an immediate jump in this probability for the covered offenses by 10 percentage points. The probability of charges continued to grow throughout the post-reform period, reaching 85 percent. For other offenses, the probability of charges rose only slightly with the reform and then levelled off.

Finally, we can observe the trends in the probability of conviction at court, conditional on being charged (Figure 6). For covered offenses, it rose gradually by 7 percentage points (to almost 90 percent) after the reform, reversing the prior downward trend. The pattern is similar for other offenses, but less pronounced in 
magnitude.

\subsection{Identifying variation}

The actual adoption of the fast-track procedure was gradual and varied widely across offenses and districts. The main reasons for such variation are the differences among offenses in the share of cases that are eligible for the fast track, and differences between districts in exercising the discretion to prosecute cases via the fast track. The latter variation allows identifying the causal effects of the fast-track procedure. Table 2 shows the mean, standard deviation, and the 5th and 95th percentiles of the share of fast-track cases for the covered offenses in 2002 (the first post-reform year) and in 2008 (the last year in our data) at the district level. The fast-track procedure became used relatively heavily in prosecuting thefts/burglaries, driving offenses, ${ }^{11}$ crimes against personal liberty, other economic/property offenses and crimes against public order. The share of the fast-track cases is highest for offenses that are typically discovered and recorded by capturing the offender, when the identity of the offender is immediately known. In particular, driving offenses had a 53\% fast-track share already in the first post-reform year - they are typically simple offenses with straightforward evidence.

The 5th and 95th percentiles demonstrate the variation in adoption. The share of fast track in driving offenses, while 53 percent on average, was 28 percent in the 5th percentile district and 82 percent in the 95th percentile district. For theft, the initial share of the fast-track cases was 23 percent, varying from 6 percent in the 5 th percentile to 43 percent in the 95th percentile. Six years later, there is an overall increase in the share of the fast-track cases, but it occurs mainly through an even

\footnotetext{
${ }^{11}$ The driving offenses include predominantly two narrower offense categories: driving-under-theinfluence, and obstruction of an official order. The latter is committed by not obeying a court's restraining order, and by far the most common violation involves driving with a suspended driver's license.
} 
higher usage among the districts at the top of the distribution. E.g., the share of fast-track cases among all covered offenses increased by 13 percentage points both on average, but only by 5 percentage points at the 5 th percentile and as much as 20 percentage points at the 95th percentile.

Endogeneity of adoption presents a concern. The law enforcers choose whether to prosecute cases via the fast-track procedure. Naturally, one may suspect that the districts experiencing higher crime levels, rising crime trends, heavy case backlog, or long case durations may adopt the fast-track procedure more intensively as a measure to cut crime. They may also adopt other measures aimed at cutting case durations, introducing an omitted variable bias.

I interviewed several Ministry of Interior, Police, and State Attorney officials to collect anecdotal evidence about the causes of the large variation across districts. In their view the differences between districts were driven first and foremost by bureaucratic inertia and ideological preferences - certain police chiefs and prosecutors being more willing to experiment with new methods than others. To a secondary degree, they were a by-product of internal guidelines that divide tasks and case types between various police sub-units. Certain officers (e.g., patrol officers) can only prosecute via the fast track while others (investigative) have discretion. The share of fast-track cases in a district is then in part determined by the share of less serious crimes that "land on the desk" of the investigative vs patrol officers. The experts reported that the investigative units generally disdain the fast-track procedure as a matter of their professional culture. In districts where the guidelines allocate more petty crimes to the investigative units, the share of fast-track cases is lower. Many factors determine the allocation of labor in the guidelines other than the concerns about the use of the fast-track procedure; the resulting share of fasttrack cases is ancillary to those factors. There was also no political pressure from the central or regional governments to adopt the fast-track procedure intensively 
in specific districts; the police districts were actually different from the political districts at the time of the reform and the police chiefs did not have counterparts in elected political officials.

According to the narrative evidence, the differences in adoption were partially driven by the relative overload of the police officers and prosecutors. Police officers in districts with higher caseload tended to adopt the fast track more intensively in order to take more cases "off the table". In districts with low caseload, the officers reported that there was no pressure to spend time and effort on learning and adopting the new procedure. The last explanation posits a relationship between the adoption intensity and the number of crimes per police officers. Excessive length of the criminal procedure was not mentioned as a factor influencing adoption. None of the anecdotal explanations postulate a correlation between the adoption intensity and the trends in case durations or other outcome variables. This is important for the identification strategy. A spurious correlation between the adoption intensity and trends in outcomes would lead to biased estimates in the difference-in-differences framework.

I check for potential determinants of the fast-track adoption. I define the share of fast-track cases among covered offenses in the first post-adoption year (2002) as a measure of adoption intensity in a district. Figure 7 plots this measure against the duration from offense to charges, duration from charges to final adjudication, and caseload (crimes per police officer) in the last pre-adoption year. It indicates that adoption is positively but very weakly related to the duration of the court phase of the procedure and to the caseload per police officer. The relationship with load is driven by several outliers (the Prague districts and Pilsen) that have very high caseload and were above-average (but not the highest) adopters. Figure 8 shows that the fast-track adoption was not related to the percentage changes in durations and load during the three years preceding the adoption. To check for endogeneity 
rigorously, I estimated numerous regression specifications explaining the share of fast-track cases as a function of pre-reform levels of case duration, caseload, crime rates, socio-economic variables, or their pre-reform trends. None of these variables were statistically significant predictors of the intensity of fast-track adoption.

\subsection{Estimation}

The variation between districts naturally calls for the difference-in-differences estimator. For covered offenses, I am able to estimate both direct and spillover effects. I estimate the following equation separately for each covered offense category:

$$
y_{o i t}=\beta_{d o} s_{o i t}+\beta_{s o} \overline{s_{i t}}+\gamma_{o} X_{o i t}+\delta_{o} \log X_{i t}+\lambda_{o i}+\lambda_{o t}+\epsilon_{o i t}
$$

where $y_{\text {oit }}$ is the outcome variable for offense $o$ in district $i$ in year $t, s_{\text {oit }}$ is the share of fast-track cases in offense $o$, while $\overline{s_{i t}}$ is the average share of the fast-track cases across all offenses (it is therefore the same for all offenses in district $i$ ). $X_{\text {oit }}$ denotes average characteristics of cases and $X_{i t}$ denotes characteristics of the criminal justice system in the district. ${ }^{12} \lambda_{o i}$ and $\lambda_{o t}$ are the district and year fixed effects, and $\epsilon_{o i t}$ is the error term. $\beta_{d o}$ and $\beta_{\text {so }}$ are the key parameters of interest. $\beta_{d o}$ has the interpretation of the direct effect: a change in outcome for offense $o$ due to a onepercentage point increase in the share of fast-track cases in offense $o$. The estimates of the spillover effects are based on the idea that the magnitude of the spillover is determined by the total amount of time and other resources that were released by the fast track. That in turn is determined by the overall share of the fast-track cases in the district $\overline{s_{i t}}$, not the share for the particular offense. $\beta_{s o}$ thus has the

\footnotetext{
${ }^{12}$ The average case and offender characteristics are: the number of charges per case, maximum statutory sentence, number of prior convictions, share of defendants in pretrial detention, defendant age, and the shares of women and foreigners among defendants. The district characteristics are: the number of crimes per police officer, number of cases per prosecutor and per court senate, and district population.
} 
interpretation of the spillover effect.

For other offenses, I estimate the spillover effect only. The estimating equation is the same as equation 1 , except that term $\beta_{d o} s_{\text {oit }}$ is omitted. ${ }^{13}$

In both sets of regressions, the parameters of interest are identified by comparing the change in the outcome variable in high-adoption districts with the change in the outcomes in low-adoption districts. The identifying assumption requires that the district-specific trends in unobservables are uncorrelated with the share of fast-track cases in a district. I emphasize that the identifying assumption does not require that the 2002 reform had no other effects; only that such effects be uncorrelated with the share of fast-track cases in a district. Standard errors are clustered by district.

\section{Results}

\subsection{Covered offenses}

The estimates of the direct and spillover effects on the covered offenses are presented in Tables 3 (durations) and 4 (probabilities). To save on space, the rows show the estimates of $\beta_{d o}$ and $\beta_{s o}$, while the coefficients on the control variables are not reported. ${ }^{14}$ The first row of Table 3 shows the effects on the duration from offense to charges. All estimated direct effects are negative, significant at 1\%, and range from -90 (driving offenses) to -346 (property/economic offenses). The size of the coefficient for, for example, theft/burglary implies that an increase in the share of fast-track cases by 10 percentage points is associated with a reduction in total duration by 12 days. In a similar vein, a 10-percentage-point increase in the share

\footnotetext{
${ }^{13}$ Most of the other offenses contain a small but non-zero fraction of fast-track cases and thus the direct effects can, in principle, be estimated. However, the share of fast-track cases is too small to generate a measurable impact on the outcomes. I estimated specification 1 for other offenses as well; however, the estimated direct effects were either small and insignificant or had implausibly large values.

${ }^{14}$ Full results are available upon request.
} 
of fast-track cases is associated with a reduction in the duration from offense to charges by 9 days for trespass, 20 days for offenses against personal liberty, 35 days for other property/economic offenses, and by 14 for offenses against public order.

The second row reports the estimated spillover effects. I find no evidence of negative spillover effects on covered offenses. The coefficients on the fast-track share in all offenses are positive but not statistically significant for four out of the five covered offenses. The main effect of the reform on covered offenses appears to be driven purely by economizing resources in enforcing each covered offense.

The lower panel of Table 3 reports the effects on the duration of the court phase, from charges to final adjudication. All estimated direct effects are also negative, and they are statistically significant at 5\% for theft/burglary and offenses against personal liberty. They imply a reduction in the court duration by 13 days associated with a 10-percentage-point increase in the share of fast-track cases. The estimated spillover effects are not statistically significant at a $5 \%$ level, and they have a positive sign.

The top panel of Table 4 reports the estimated effects on the probability that the defendant is charged, conditional on being identified as suspect. The direct effects are positive, significant at $1 \%$ for four out of five offenses, and large in magnitude. A 10-percentage-point increase in the share of fast-track cases is associated with an increase in the probability of charges by 1.3 percentage points for theft/burglary, 2.2 percentage points for driving offenses, 2.3 percentage points for offenses against personal liberty, and 3 percentage points for other property/economic offenses. The spillover effects have varying signs. The only significant spillover effect is found for driving offenses and it is negative, implying a perverse spillover effect that actually lengthens duration. Finally, the regressions in the bottom panel of Table 4 reveal no discernible direct or spillover effects on the probability of conviction at trial, conditional on the case reaching the trial. This is an important finding. The fast- 
track procedure simplified many steps and could have potentially deteriorated the defendants' rights to the extent that more of them would be (unjustly) convicted at trial. The last finding indicates that it was not the case and the courts appear to have applied the same standard for conviction in the fast-track cases as in the conventional cases.

The results for covered offenses are consistent with the hypothesis that the simplified criminal procedure had desirable causal effects on the petty offenses that the reform explicitly targeted. It significantly reduced case durations, particularly in the police/prosecutor phase of the procedure. It also significantly increased the probability that the prosecutor successfully completes the prosecution and brings the charges to the court.

\subsection{Other offenses}

The estimates of the spillover effects on the duration of other, non-covered offenses are presented in Table 5. There is only one negative and statistically significant spillover effect: on the duration from offense to charges for sex offenses (a 10percentage-point increase in the overall fast-track share being associated with shortening the duration by 34 days). The spillover effects on the duration from offense to charges are small, insignificant, and with varying signs for all the remaining offenses. The same is true of the estimated spillover effects on the duration from charges to final adjudication. Not only are the estimated spillover effects insignificant, but the regressions explaining the case durations of other offenses have generally lower explanatory power than corresponding regressions for covered offenses.

The evidence of spillover effects on the probability of charges or the probability of conviction is also very weak (Table 6). The estimated effect on the probability of charges is positive and economically significant for all offenses but one, in particular for robbery (0.08), sex offenses (0.12), offenses against family (0.09) and against 
public safety (0.12). However, it is statistically significant only for offenses against family. No spillover effects are detected for the probability that the defendant is convicted at trial. All the estimates are statistically insignificant and generally small in magnitude.

I experimented with alternative specifications that could potentially gauge the spillover effects more precisely. In one, the overall share of the fast-track cases was replaced with the share of fast-track cases among the covered offenses only. In another, I constructed the average share of fast-track cases weighted by an index of case difficulty. The fast-track procedure plausibly released more enforcement resources in districts that implemented it on relatively more difficult cases, holding the overall share of fast-track cases constant. Using the case-level data, I construct an index of case difficulty at the level of a very narrow offense definition (the section and subsection of the criminal code). The index is equal to the average case duration in the last pre-reform year. The weighted share of fast-track cases is then constructed at the level of offense, district, and year. Nevertheless, this procedure produced estimates of the spillover effects that were very similar to the specifications using a simple fast-track share.

\section{Conclusions}

The paper provided evidence that introducing a simpler criminal procedure has some important effects on the outcomes of criminal cases. In the Czech context, the simpler procedure was implemented on a subset of petty offenses. The main finding is that it reduced the duration of the criminal procedure precisely for those (covered) offenses. The reduction in duration was particularly concentrated in the police/prosecutor phase of the procedure.

The estimated direct effects on covered offenses are economically significant. In or- 
der to evaluate their economic significance, I compare the change in actual duration with a change in counterfactual duration. To construct the counterfactual, I use the regression coefficients from Table 3 to predict the duration after the reform, under the assumption that the share of fast-track cases would have remained zero throughout the post-reform period while the case, offender, and district characteristics, the year dummies and district trends would have evolved as they actually did. Table 7 reports the results of these simulations. For example, the average duration from offense to charges for theft/burglary cases was 168 days in the last year before the reform. It declined by 33 days during the post-reform period. The regressions estimates imply that in the absence of the fast-track procedure, the duration would have declined as well, but by 13 days only. The fast-track procedure, as actually implemented to prosecute theft/burglary cases, accounts for 20 days of the reduction in duration. The contribution of the fast-track procedure was particularly pronounced in driving offenses and other property/economic offense, where it accounts for a reduction in case duration by 60 and 54 days, respectively. On average, the duration from offense to charges declined by 55 days, of which 27 days is attributable to the fast-track procedure.

The second main finding is a direct effect on the probability that the accused defendant is eventually charged with court. The fast-track procedure can therefore be thought of as a "technological improvement" that allowed the police and prosecutors to successfully complete a higher fraction of cases all the way to charging the defendant. As for the economic significance, the bottom panel of Table 7 reports the results of an analogous counterfactual exercise. The probability of charges in theft cases increased by 17 percentage points during 2001-2008, from 66 percent to 83 percent. If the share of fast-track cases were zero, it would have increased by 10 percentage points only. The fast-track procedure thus contributed 7 percentage points to this increase. It had a similarly large effect on driving offenses and offenses against personal liberty. On average, it accounts for 6 percentage points out of the 
11-percentage-point actual increase in the probability of charges.

The particular findings are of course context-specific to the Czech criminal procedure reform. However, they provide insights into some general questions in the economics of criminal procedure. On the policy side, the reform demonstrates that countries burdened with an overly lengthy and ineffective criminal justice process do not necessarily have to hire more police officers, prosecutors, or judges. Simplifying the procedure can reduce the procedural delays and increase the output of the enforcement officials. The lack of an effect on the probability of conviction at trial indicates that such an improvement in productivity can be achieved without compromising the standard of proof.

The reform saved enforcement resources in a subset of cases (petty offenses). In this sense, it was conceptually similar to introducing plea bargaining. The estimates of the spillover effects thus provide an indirect test of the hypothesis that plea bargaining releases resources and increases the prosecutors' productivity even in cases that reach trial. These beneficial spillovers onto other, more serious offenses was in fact an explicit objective of the reform. However, I find essentially no evidence of such spillover effects (with the possible exception of a statistically weak spillover on the probability of charges for several serious offenses).

Why is there an absence of significant spillover effects? The theoretical framework of section 3 provides a possible explanation. The spillover effect is a product of two underlying behavioral responses: the scale and substitution effects. The benefits of plea bargaining and similar cost-reducing procedural alternatives stem only from the scale effect. The substitution effect, however, is driven by the incentive of the law enforcers to allocate resources towards offenses that are "cheap" (from their perspective) to enforce. The magnitude of the substitution effect depends on the willingness of the enforcement officials to substitute the enforcement of the petty offenses for the serious offenses. The fast-track procedure reduced the relative cost of prosecuting 
petty offenses. As I demonstrate in Dušek (2014), it led to an increase in the number of (recorded) driving offenses, a finding that is consistent with a fairly sizable willingness to substitute the enforcement of various types of offenses depending on the cost of enforcement. The potential spillover effects on serious offenses may thus have been largely undone by the reallocation of enforcement resources towards petty offenses.

\section{References}

[1] Beenstock, M. and Haitovsky, Y. (2004). Does the appointment of judges increase the output of the judiciary? International Review of Law and Economics, Vol 24 (3), pp. 351-369.

[2] Boari, N. and G. Fiorentini (2001). An economic analysis of plea bargaining: the incentives of the parties in a mixed penal system. International Review of Law and Economics, Vol. 21 (2), pages 213-231.

[3] Bridges, G.S. (1982). The speedy trial act of 1974: The effects on delays in federal criminal litigation, Journal of Criminal Law and Criminology, Vol. 73 (1), pp. 50-73.

[4] Dimitrova-Grajzl, V., Grajzl, P., Sustersic, J., and Zajc, K. (2012). Court output, judicial staffing, and the demand for court services: Evidence from Slovenian courts of first instance. International Review of Law and Economics, Vol. 32 (1), pp. 19-29.

[5] Dušek, L. (2014): Time to punishment: The effect of a shorter criminal procedure on crime rates, in print, International Review of Law and Economics. Available at http://papers.ssrn.com/sol3/papers.cfm?abstract_id=2334591. 
[6] Easterbrook, F (1983): Criminal Procedure as a Market System. Journal of Legal Studies Vol 12, pp. 289-332.

[7] Huang, B. (2011). Lightened Scrutiny, Harvard Law Review, Vol. 124 (5), p. 1109.

[8] Kaplow, L. (2012). On the optimal burden of proof. Journal of Political Economy, Vol. 119, No. 6 (December 2011), pp. 1104-1140.

[9] Landes, W.M. (1971) An Economic Analysis of Courts. Journal of Law and Economics, Vol. 14, No. 1, pp. 61-107.

[10] Pellegrina, L.D. (2008) "Court Delays and Crime Deterrence. An application to crimes against property in Italy." European Journal of Law and Economics, Vol. 26, pp.267-290.

[11] Rizzolli, M. (2011). Better that ten guilty persons escape: punishment costs explain the standard of evidence. Public Choice, August 2011.

[12] Soares, Y., and Sviatschi, M.M. (2010) "Does Court Efficiency Have a Deterrent Effect on Crime? Evidence for Costa Rica", unpublished manuscript, available at http://www.inesad.edu.bo/bcde2012/papers/ 7.\%20Sviatschi_Crime\%20and\%20Efficiency.pdf

[13] Zeman, P., L. Hakova, Z. Karabec, P. Kotulan, V. Necada, H. Preslickova, J.Vlach (2008) "Vliv Vybranych Ustanoveni Velke Novely Trestniho Radu Na Prubeh Trestniho Rizeni." Institut Pro Kriminologii A Socialni Prevenci. 
Figure 1: Constraints and preferences of enforcement officials

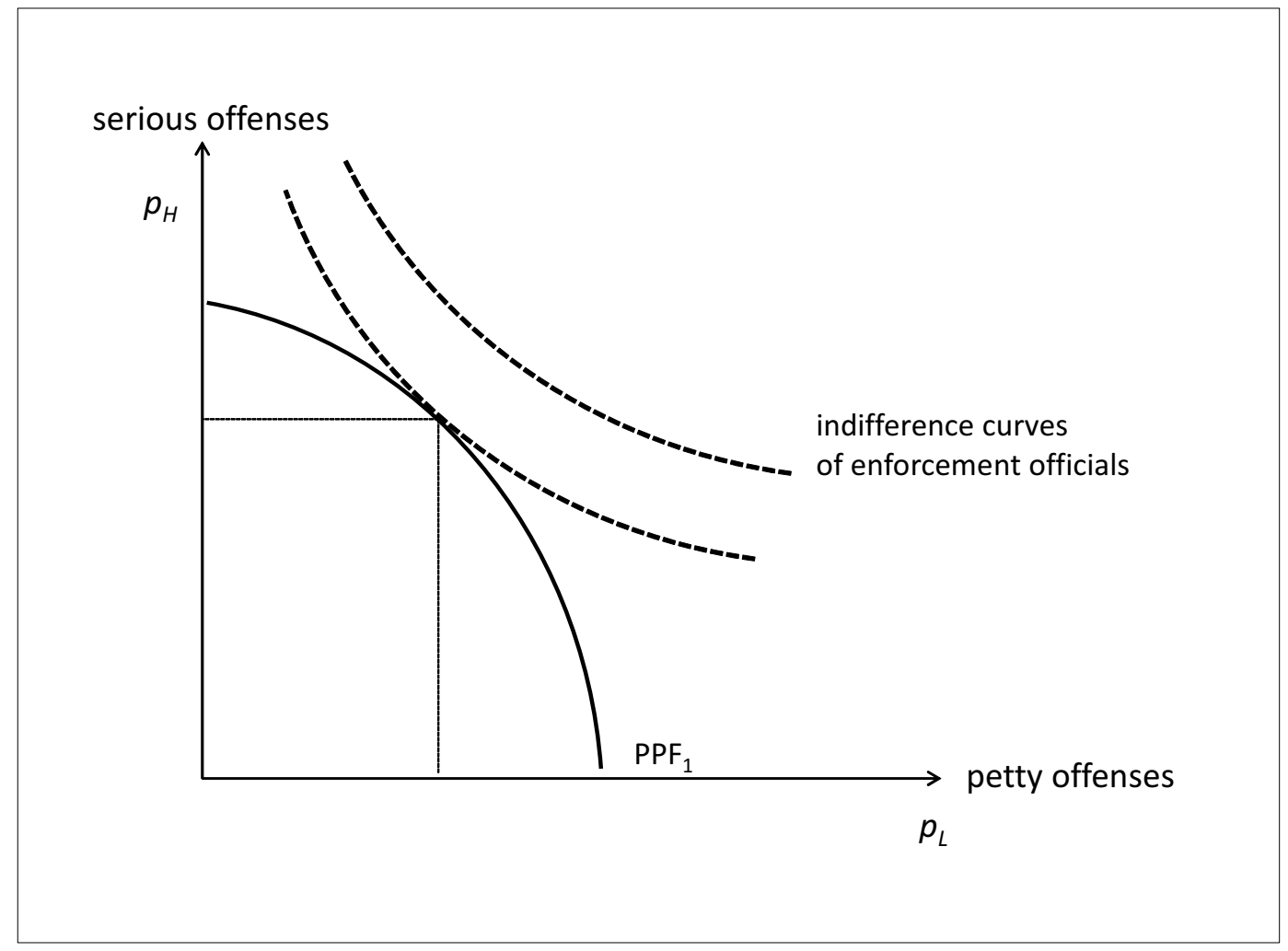

Figure 2: Response to a decrease in the cost of enforcing petty crimes

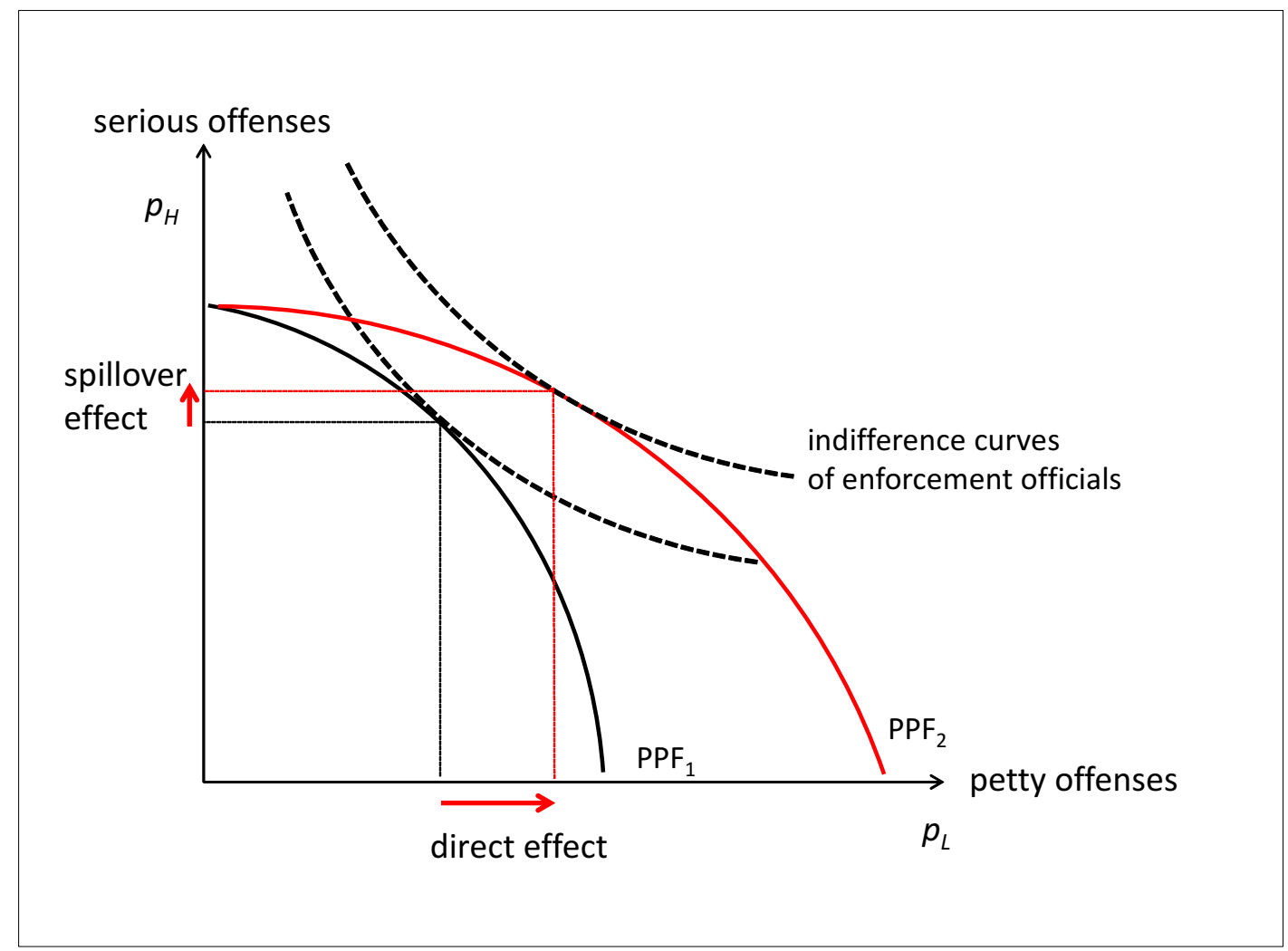


Figure 3: Average duration from offense to charges, by offense types

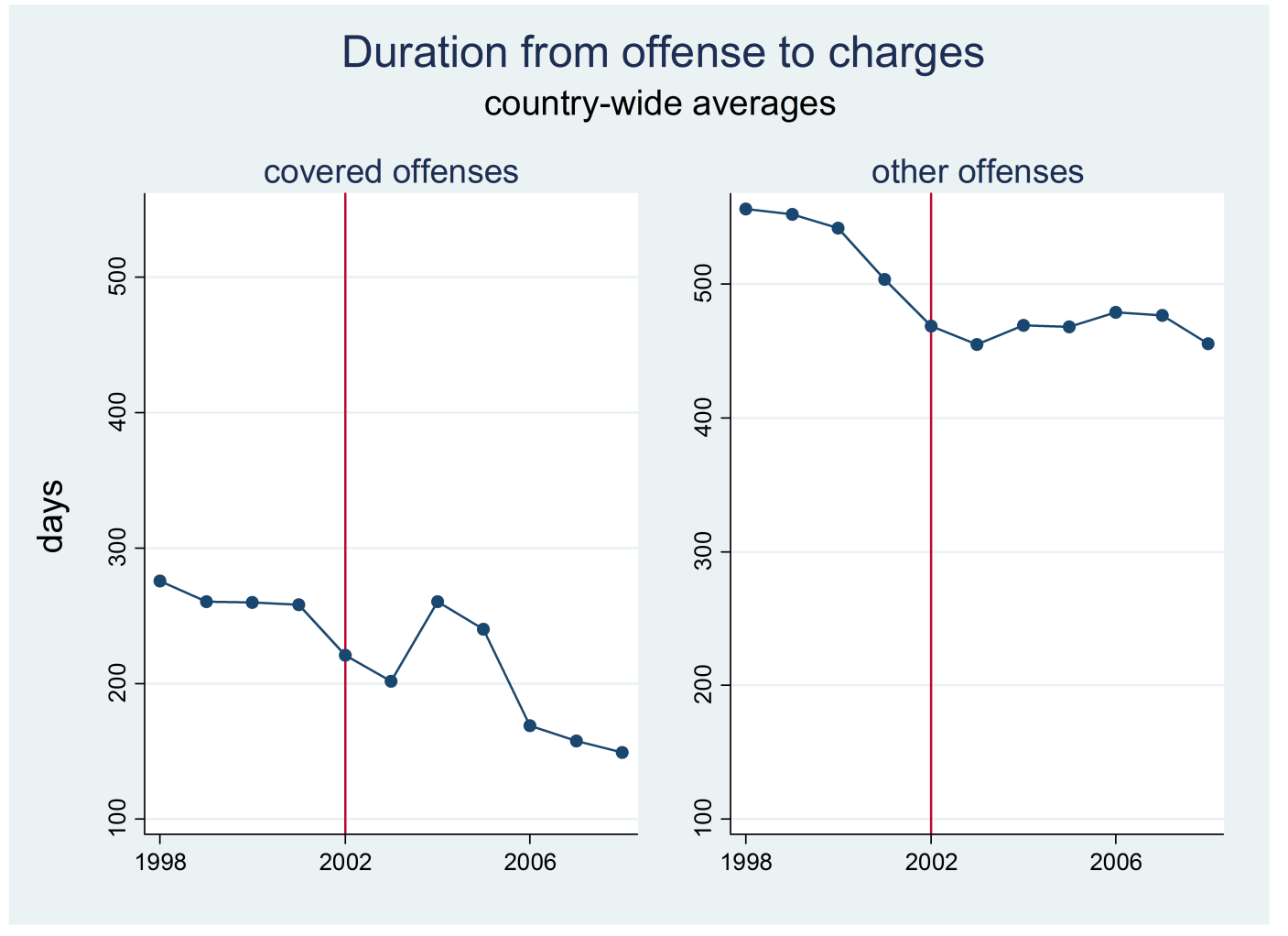

Figure 4: Average duration from charges to final adjudication, by offense types

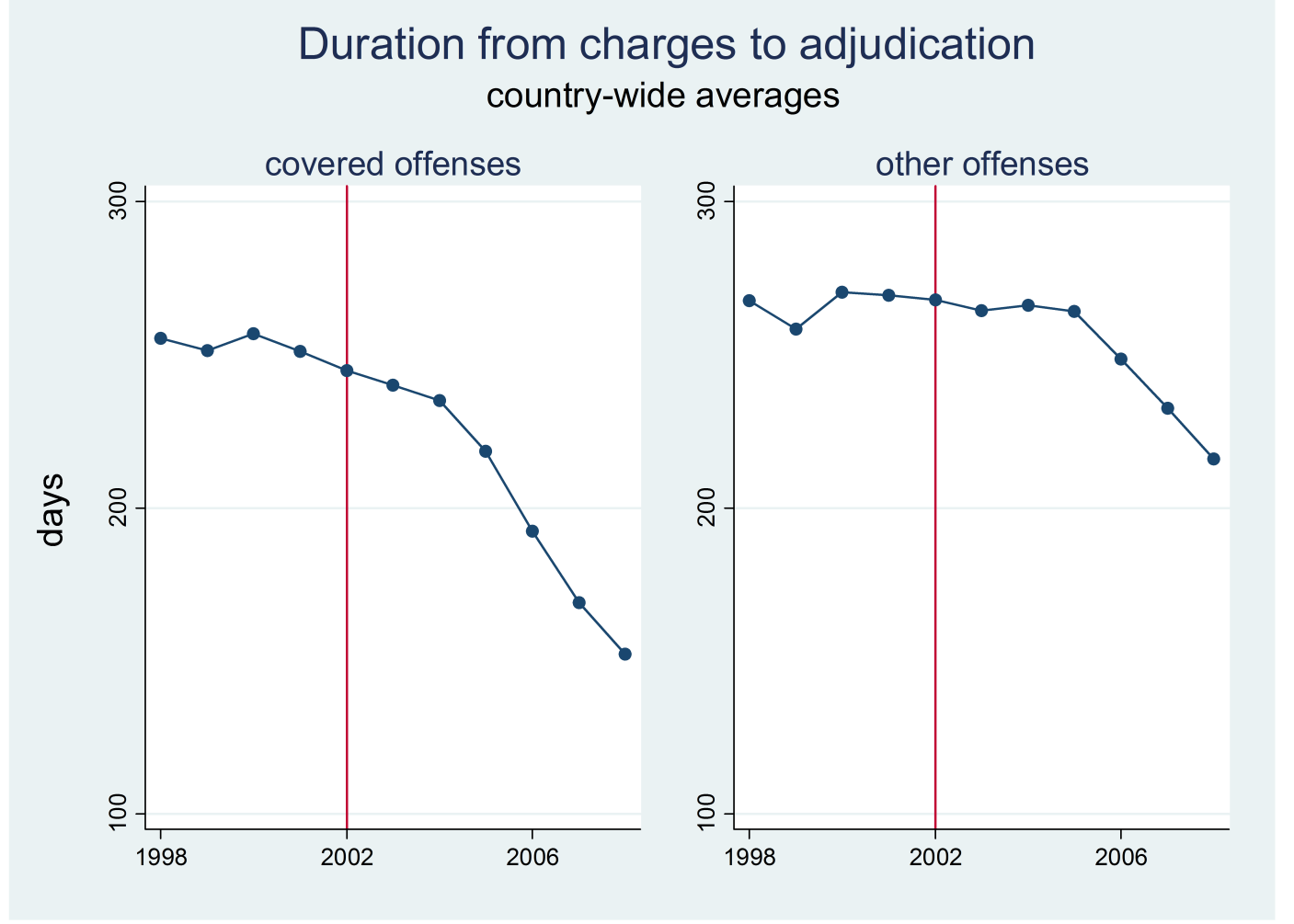


Figure 5: Average probability of charges, by offense types

\section{Probability of charges country-wide averages}
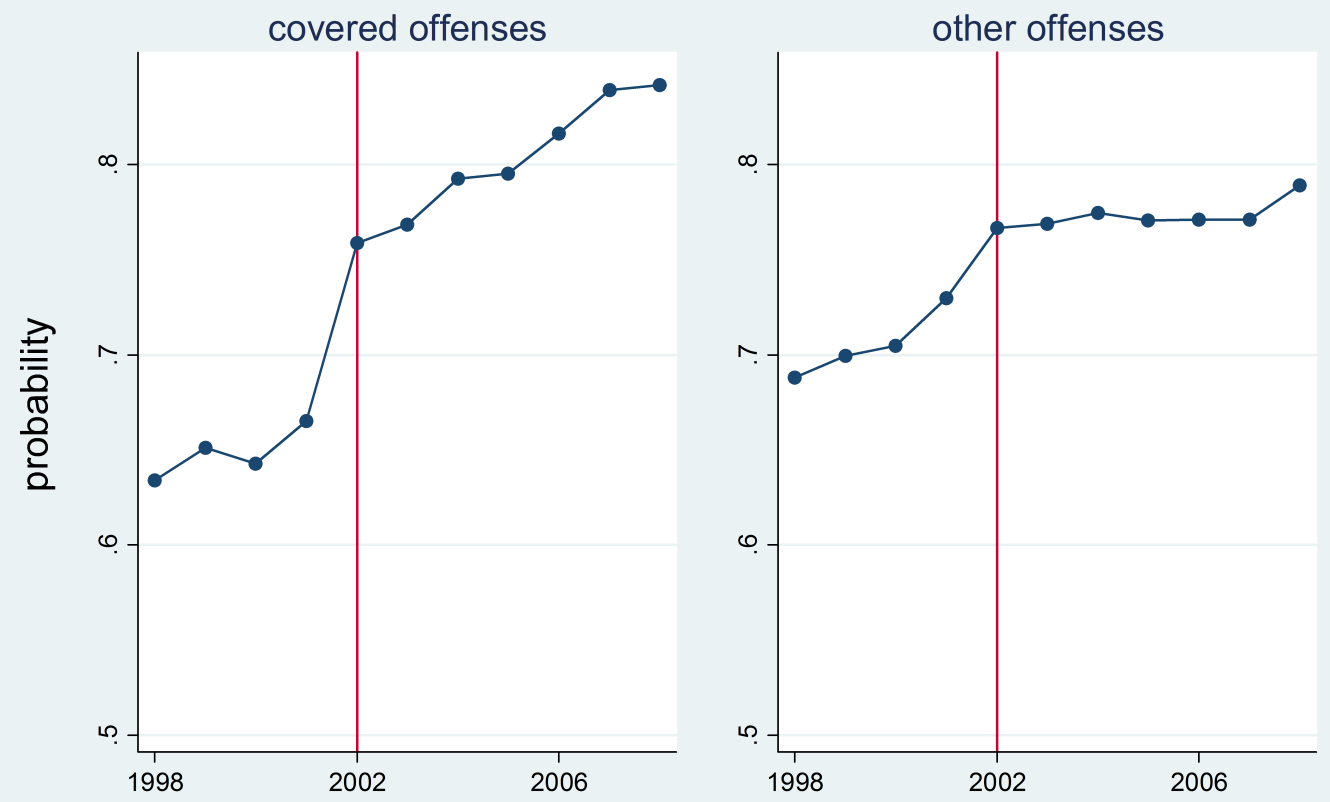

Figure 6: Average probability of conviction, by offense types

\section{Probability of conviction country-wide averages}
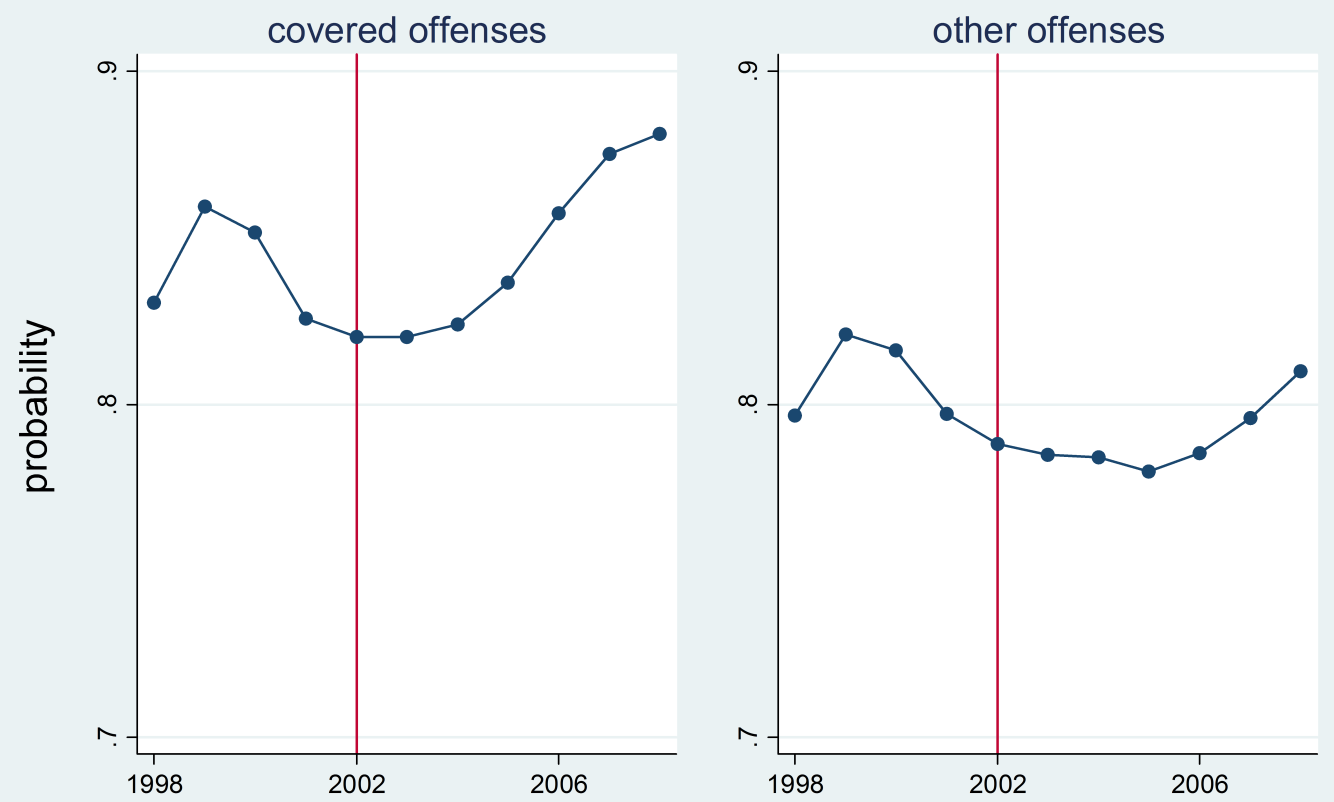
Figure 7: Endogeneity of fast-track adoption: levels

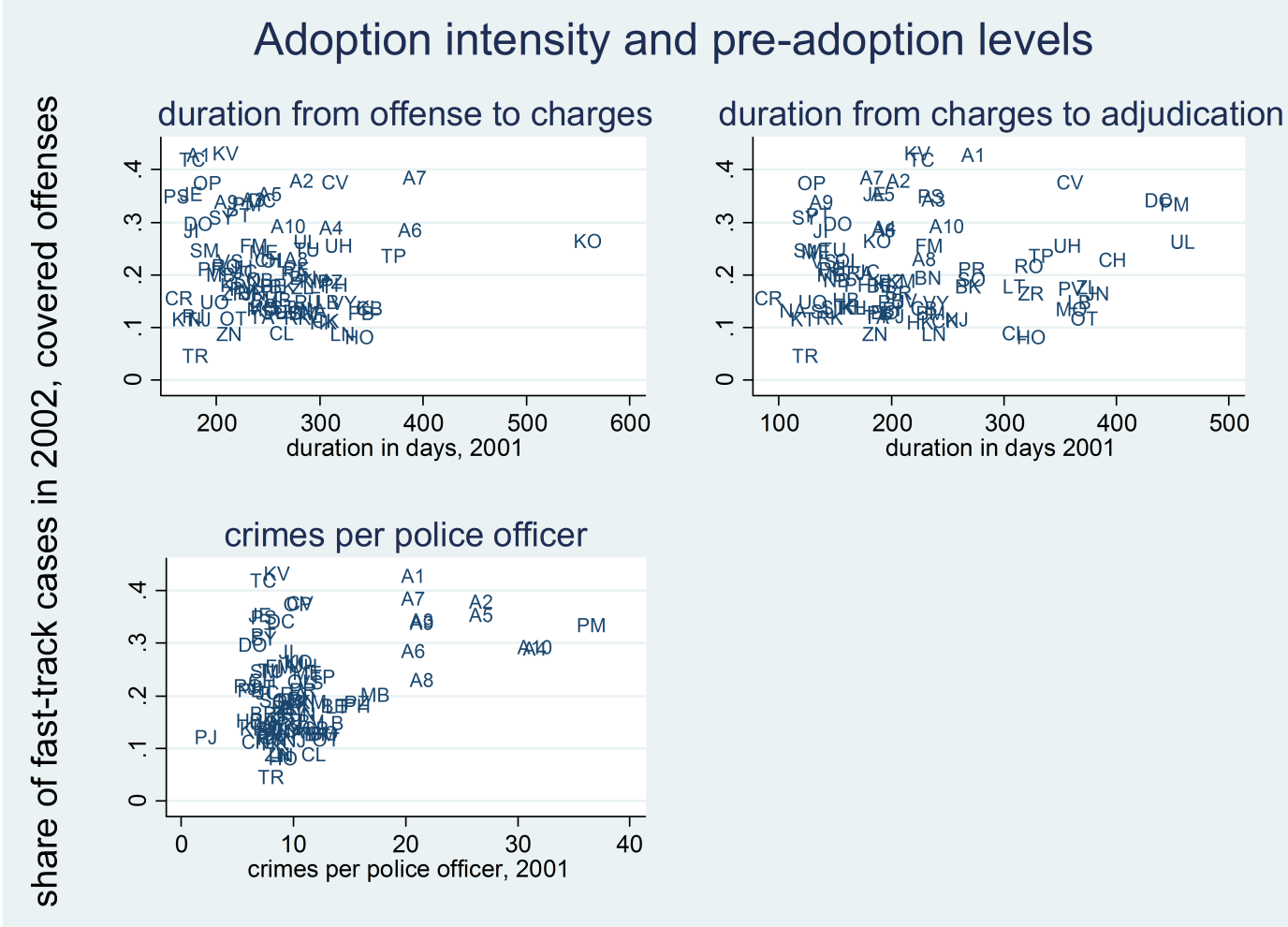

Figure 8: Endogeneity of fast-track adoption: trends

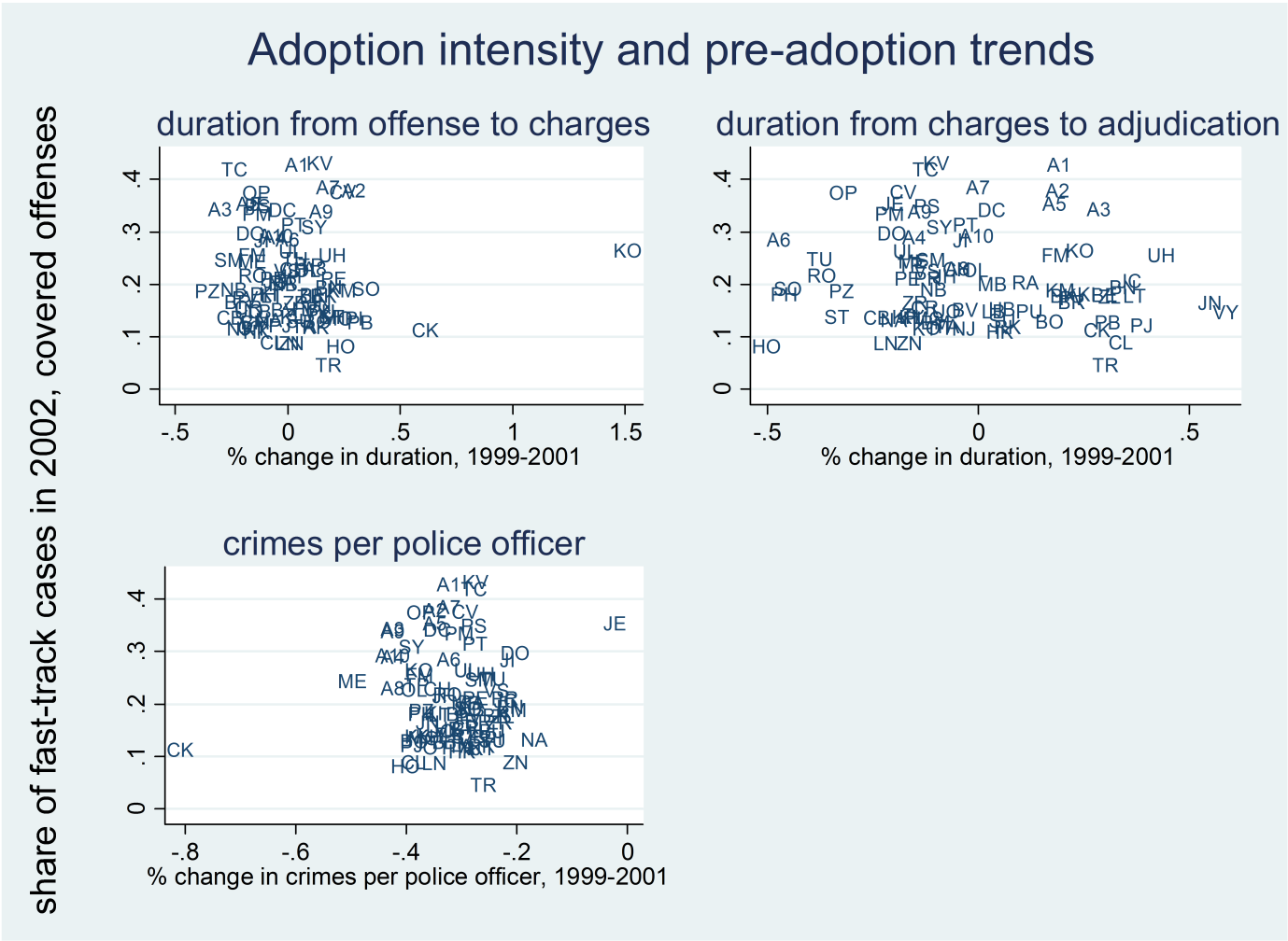


Table 1: Summary statistics

\begin{tabular}{lrrrrrr}
\hline \multirow{2}{*}{ variable } & \multicolumn{3}{c}{ pre-reform } & \multicolumn{3}{c}{ post-reform } \\
\cline { 2 - 7 } share of fast-track cases & obs & mean & sd & obs & mean & sd \\
\hline duration from offense to charges (days) & 3782 & 0 & 0.02 & 6618 & 0.15 & 0.20 \\
duration from charges to adjudication (days) & 3778 & 362.25 & 250.15 & 6617 & 309.75 & 220.20 \\
probability of charges & 3782 & 0.68 & 0.15 & 6618 & 0.78 & 0.14 \\
probability of convictions & 3775 & 0.83 & 0.12 & 6612 & 0.82 & 0.11 \\
number of charges per case & 3782 & 1.34 & 0.32 & 6618 & 1.36 & 0.31 \\
share of defendants in pre-trial detention & 3775 & 0.16 & 0.19 & 6612 & 0.10 & 0.15 \\
number of prior convictions & 3775 & 1.91 & 0.94 & 6612 & 2.38 & 1.05 \\
share of female defendants & 3782 & 0.10 & 0.07 & 6618 & 0.11 & 0.08 \\
share of foreign defendants & 3782 & 0.06 & 0.09 & 6618 & 0.06 & 0.09 \\
defendant age & 3782 & 29.79 & 4.17 & 6618 & 31.08 & 4.30 \\
crime rate (offenses per 100,000) & 3784 & 0.04 & 0.03 & 6622 & 0.03 & 0.02 \\
crimes per police officers & 3784 & 16.25 & 11.18 & 6622 & 10.95 & 5.93 \\
cases per prosecutor & 3784 & 104.91 & 36.54 & 6622 & 97.62 & 30.02 \\
cases per court senate & 3784 & 144.23 & 35.54 & 6622 & 417.92 & 549.29 \\
\hline
\end{tabular}

Note: summary statistics computed at the level of district-year-offense.

Table 2: Variation across districts

Share of fast-track cases in 2002 (\%)

\begin{tabular}{lcccc}
\hline offense category & mean & sd & p5 & p95 \\
\hline theft/burglary & 23 & 11 & 6 & 43 \\
driving offenses & 53 & 17 & 28 & 82 \\
against personal liberty & 12 & 8 & 2 & 28 \\
property/economic offenses & 10 & 8 & 2 & 26 \\
against public order & 14 & 10 & 2 & 32 \\
\hline all covered offenses & 22 & 19 & 2 & 65 \\
\hline
\end{tabular}

Share of fast-track cases in $2008(\%)$

\begin{tabular}{lcccc}
\hline offense category & mean & sd & p5 & p95 \\
\hline theft/burglary & 35 & 11 & 19 & 57 \\
driving offenses & 76 & 11 & 60 & 92 \\
against personal liberty & 21 & 12 & 5 & 45 \\
property/economic offenses & 21 & 12 & 6 & 45 \\
against public order & 23 & 12 & 5 & 46 \\
\hline all covered offenses & 35 & 24 & 7 & 85 \\
\hline
\end{tabular}




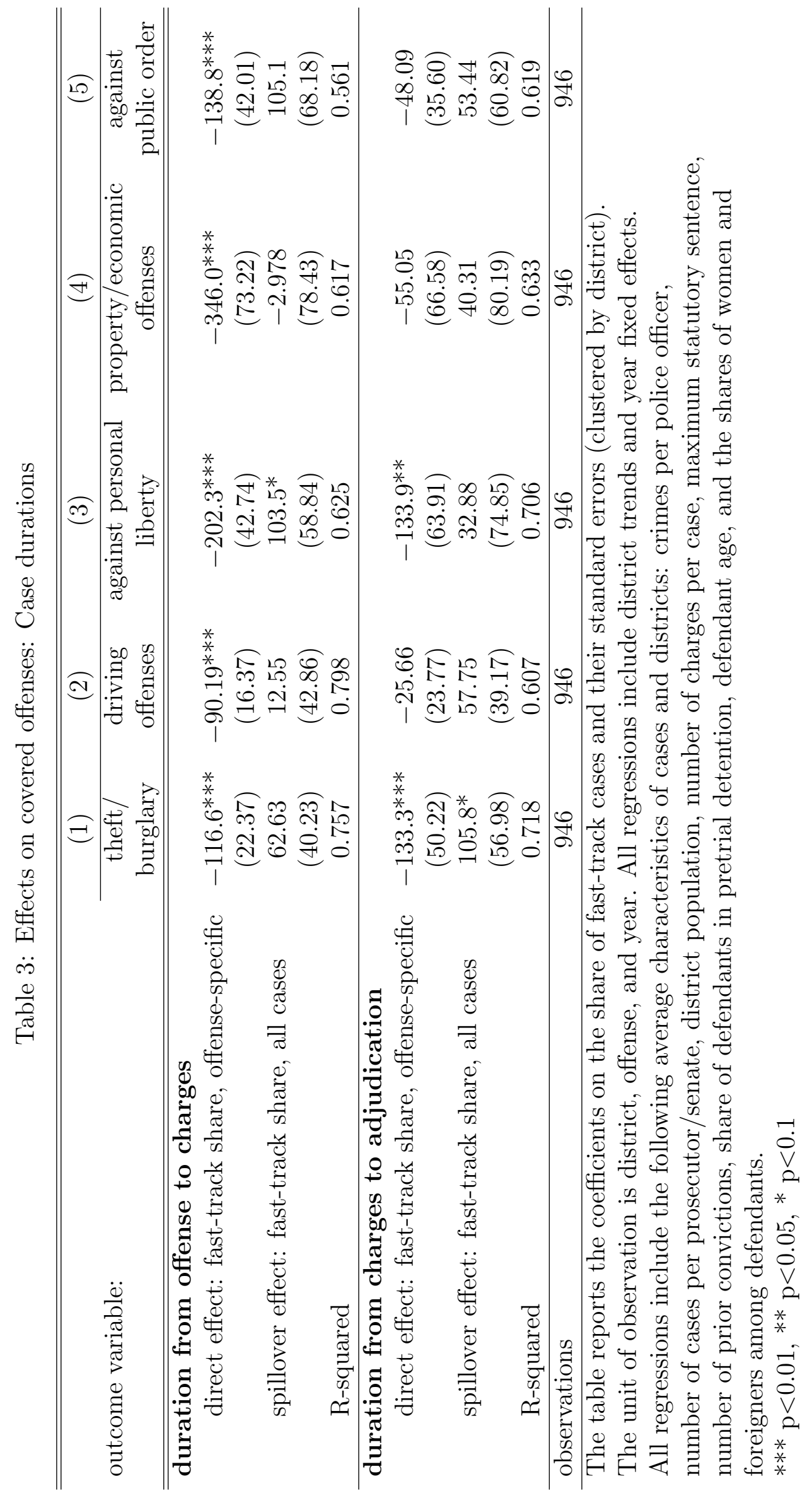




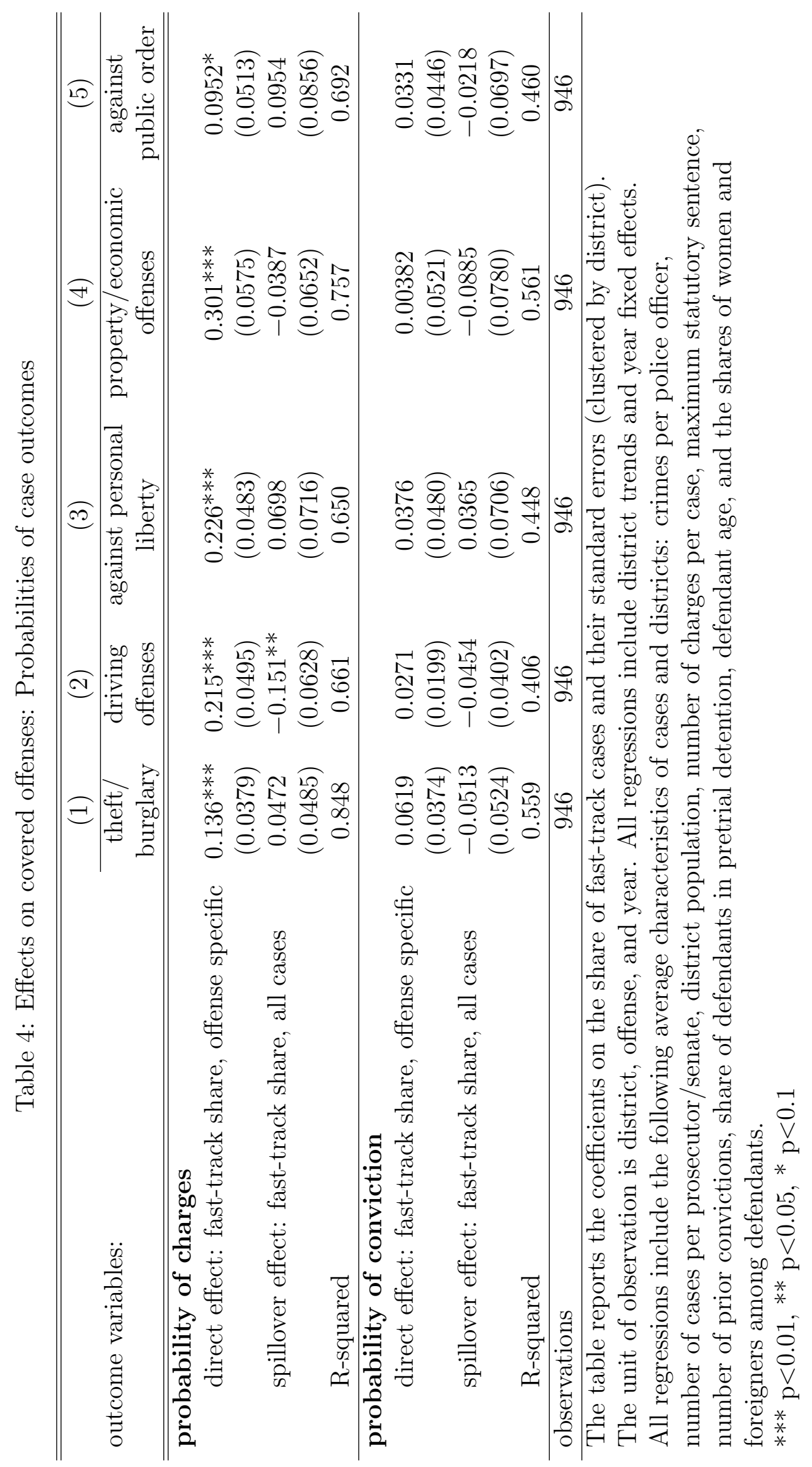




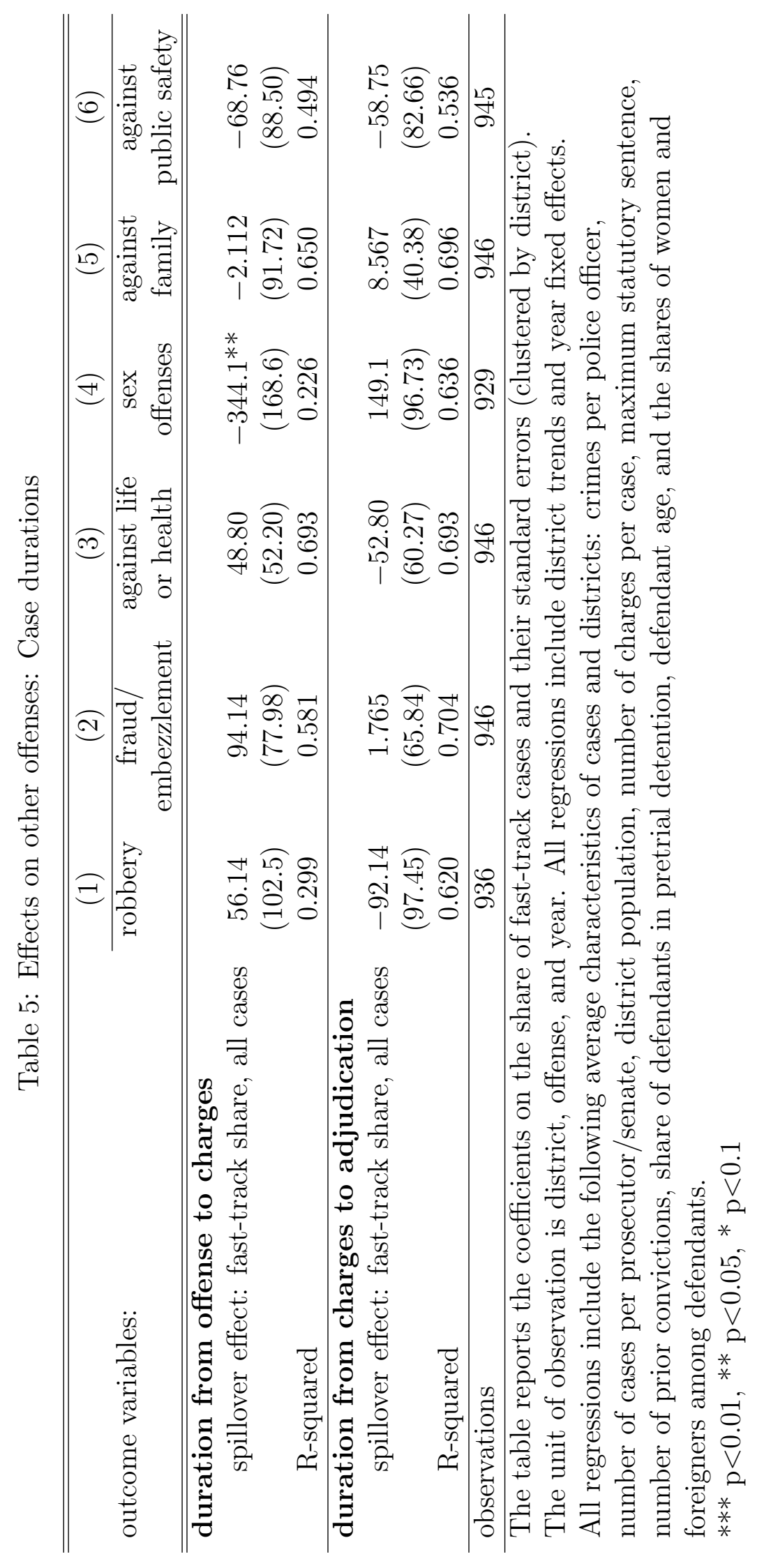




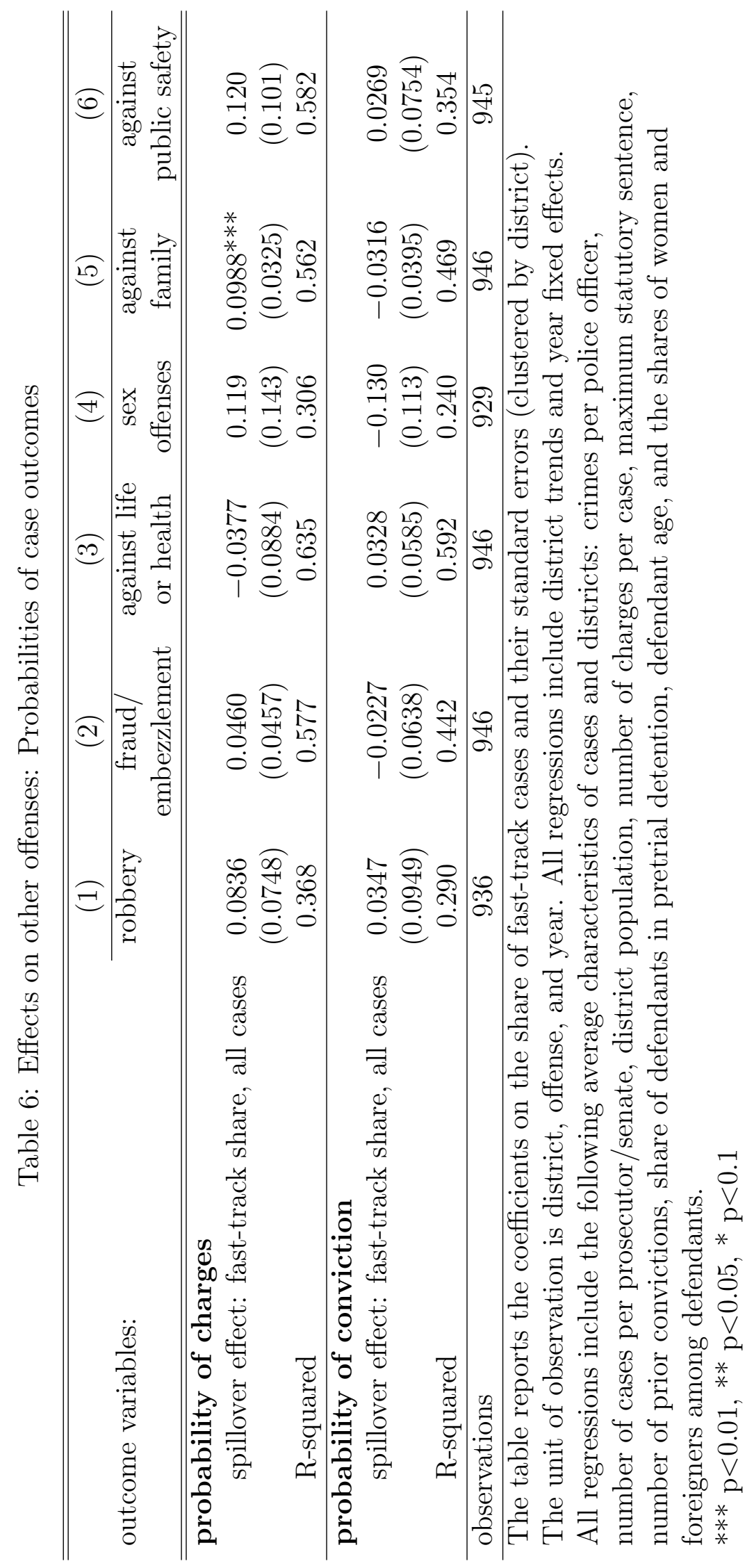




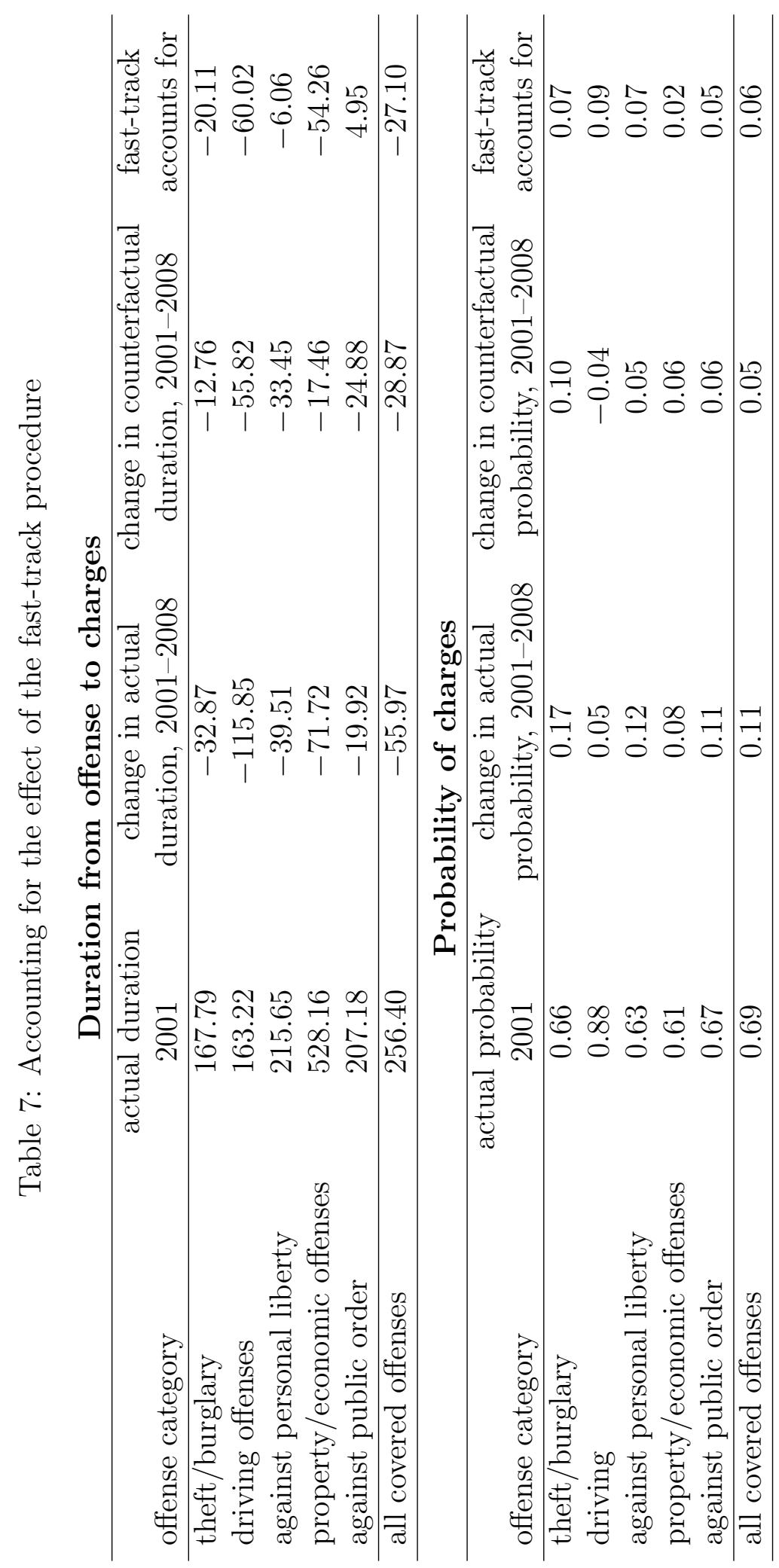




\section{Working Paper Series}

ISSN 1211-3298

Registration No. (Ministry of Culture): E 19443

Individual researchers, as well as the on-line and printed versions of the CERGE-EI Working Papers (including their dissemination) were supported from institutional support RVO 67985998 from Economics Institute of the ASCR, v. v. i.

Specific research support and/or other grants the researchers/publications benefited from are acknowledged at the beginning of the Paper.

(c) Libor Dušek, 2015

All rights reserved. No part of this publication may be reproduced, stored in a retrieval system or transmitted in any form or by any means, electronic, mechanical or photocopying, recording, or otherwise without the prior permission of the publisher.

Published by

Charles University in Prague, Center for Economic Research and Graduate Education (CERGE) and

Economics Institute of the ASCR, v. v. i. (EI)

CERGE-El, Politických vězňů 7, 11121 Prague 1, tel.: +420 224005 153, Czech Republic.

Printed by CERGE-EI, Prague

Subscription: CERGE-EI homepage: http://www.cerge-ei.cz

Phone: + 420224005153

Email: office@cerge-ei.cz

Web: http://www.cerge-ei.cz

Editor: Marek Kapička

The paper is available online at http://www.cerge-ei.cz/publications/working_papers/.

ISBN 978-80-7343-333-8 (Univerzita Karlova. Centrum pro ekonomický výzkum a doktorské studium)

ISBN 978-80-7344-325-2 (Akademie věd České republiky. Národohospodářský ústav) 
CERGE-EI

P.O.BOX 882

Politických vězňů 7

11121 Praha 1

Czech Republic http://www.cerge-ei.cz 